\title{
Understanding the Corona Virus Pandemic: From a Sociological Perspective
}

\author{
Dr. Niharika Mohapatra \\ *Post-doctoral fellow, ICSSR \\ DOI: 10.29322/IJSRP.10.06.2020.p10219 \\ http://dx.doi.org/10.29322/IJSRP.10.06.2020.p10219
}

\begin{abstract}
The present corona virus pandemic that the world is facing today is the biggest crisis after the Second World War. It possesses a serious threat to all aspects of development, having wider social, physical, psychological, economic and political implications. So in this paper I attempt to analyze how we as sociologists would contribute to the understanding of this outbreak and help in reducing its impact and contribute in the policy level.
\end{abstract}

Index Terms- Corona Virus, Pandemic, Risk Society, Sociological Perspective

\section{INTRODUCTION}

$\mathrm{P}$ andemics can be petrifying. They are mass murderers as they ruin families, dismantle towns, and leave a generation blemished and panic stricken. Pandemics are not like anything else that people confront, as it can throw certainty out of the window. The World Health Organization (WHO) defines 'pandemic as a worldwide spread of a new disease'. The present corona virus pandemic is the biggest crisis after the Second World War. The number of people affected by the corona virus pandemic is increasing each day globally and in India, infecting close to 4.5 million $^{1}$ people worldwide and in India the number has crossed 70,000 , still likely to increase. A pandemic like this presents a serious threat to all aspects of development, having wider social, physical, psychological, economical and political implications. So in this paper I attempt to analyze and question myself how we as sociologists would contribute to the understanding of this outbreak termed as a notified disaster by the Indian Government and help in reducing its impact and contribute in the policy level.

\section{The Corona Virus Pandemic: From a Sociological PERSPECTIVE}

A disaster sociologist would study the human aspects i.e. the human adaptation, behaviour, perception and response, of this corona virus outbreak rather than just the physical damage it is causing. The study of human aspects of this pandemic is crucial because of the finely developed ability of human beings to put themselves at risk (Hewitt, 1983). One of the immediate responses in such a large-scale outbreak could be mass panic, widespread disorganization and hysteria. Panic occurs during disasters when an immediate risk is perceived to be present in which the at- risk population apprehends that his escape routes are blocked and he feels highly isolated (Demerath and Wallace, 1957; Killian, 1954: 68; Quarantelli, 1954, 1957). For instance - when the government of India enforced lockdown as a measure to contain the virus, it created panic among the people as they rushed in large numbers to markets to gather essential commodities with the fear that they might face scarcity of resources, but reversing the containment strategy of the government, they risked not only their own lives but of the community as a whole.

Risk society is part of our everyday life. Risk society incorporates a specific perspective on the way in which we experience risks to health. Ulrich Beck in his book Risk Society: Toward a New Modernity, 1992, defines risk as 'a systematic way of dealing with hazards and insecurities induced and introduced by modernization itself'. With the increasing complex and technological driven society come new risks which can no longer be directly experienced in a sensory manner (touched, seen or smelt). Beck relates this risk society to a wide-ranging change which he calls 'reflexive modernization', in which progress can turn into self-destruction and one kind of modernization undercuts and changes another. For instance - the present corona virus outbreak is the result of how humans interacted with the natural world. The pressure of population growth and the dearth of 'modernization' of the economy and other institutions drive human subjugation of an unforgiving nature. Human health is closely linked to how we treat the natural world. As human beings we eat, trade body parts of wild animals, engage in deforestation which is greatly decreasing the biological barriers that kept the viruses prevailing in animals from affecting humans.

The risk society created by the corona virus pandemic leads to a vulnerable society. It showed how the society created conditions in which people faced the crisis differently. It means some groups were more prone to the damage, loss and sufferings than others. Sociologically speaking there were variations in impact on the basis of class, caste, occupation, ethnicity, gender, age, disability, health status, immigration status (both legal and illegal) etc.

Are the patterns of cleavages reestablished or changed due to the coronavirus outbreak? Class is a major form of social stratification in India. The deadly outbreak has pointed out the

\footnotetext{
${ }^{1}$ This information on the number of people infected by coronavirus is obtained from https://www.worldometers.info/coronavirus/country/india/
} 
fatal gap between the haves and have-not. When the government of India announced the national lockdown and social distancing as a potent measure to contain the virus, it pointed out the workforce inequality as only the white-collar workers could keep their jobs and work from home, but the blue-collar workers (for e.g. people engaged in delivering groceries, pharmaceutical staff, daily wage earners, petty shop owners, service providers like barbers, maids etc) who were mostly engaged in 'essential' jobs did not have the option of working from home, but lived with the fear of being rendered jobless. These blue-collar workers were at constant risk of the virus due to their position in society, this revealed a lot of the deeper structural problems with the way we structure our social life. According to an estimate provided by the International Labour Organization (ILO), only 22 percent of India's workforce comes under the category of salaried employment and 78 percent of India's workforce has no guaranteed salary, lack decent working conditions and social security, hence bore the heavier burden of the pandemic and its recovery than the relatively betteroff.

The risks involved in disasters are connected with the vulnerability created for many people through their normal existence. The differential impact of the coronavirus outbreak can be understood by a basic structural phenomenon unique to India i.e. the caste system. Due to the coronavirus outbreak the lower castes in India fear that it will strengthen the inequality among the lower caste and upper caste. There were numerous instances of caste based discrimination faced by the Yanadi community in Vijaywada, Andra Pradesh, who live in small pockets on the outskirts of the village which was considerably far off from the essential services of the village like health care centres, schools, banks etc. The people from these communities were not allowed to purchase essential items like medicine, food from the market, by the higher caste community members. The families of these communities are mostly engaged as waste pickers and drain cleaners for centuries, but with the spread of the disease they are at considerable risk of catching the virus, as they are not given enough equipment to protect themselves against the disease. With the repeated instructions on social isolation and social distancing there is a distress among the lower caste they would face more stigmatization from the higher caste communities, as they already being called by the name of the disease i.e. 'corona'. This exposes them to another form of risk i.e. discrimination.

Although the government of India has announced a stimulus relief package for the sanitation workers but to claim the government aid, the sanitation workers need to have a government Id or employment ID card. But there are many sanitation workers belonging mostly to the lower caste, who work as informal labourers and so do not possess employment ID or the government ID. It is because either the information did not reach them or the enrollment camps to get IDs have never been set up in their villages and in some cases they were asked to pay huge bribes to make these IDs done, which was not possible for them to pay. There are also some instances in which the lower castes did not have a bank account to access the government aid and those who had a bank account, do not know how to operate it because either it is controlled by the ration card shopkeeper or upper caste landlord. This clearly points out that the process of relief can see the exclusion of several groups from the lower castes if the relief packages are centralized and linked to government IDs.
Crisis always have had adverse impacts on the lives of women and the corona virus pandemic is no exception. Women were traditionally considered as care givers and nurturers; hence one of immediate impacts of the corona virus outbreak is the increased care-giving responsibilities on women. They had to take care of the children, elderly, and disabled and at the same time perform household duties. As a result of which women are found to be more stressed than men during the lockdown. It is because even today gender equality remains a concern in many families (both in rural and urban areas) due to the absence of self-corrective measures to correct gender responsibilities. The increased workload on women would have an impact on the labour force participation especially for the women working in the informal sector, for e.g. women engaged in providing tiffin service, selling fish and vegetables, construction etc. With the economy sinking even in the formal sectors women are likely to face lay off than men as they are not considered as bread winners of the family and are considered as 'less productive' than men. With the economic constraints in poorer households in matters of resource allocation relating to food, health and education, priority would be given to men and boys in availing resources instead of women and girls. There are numerous instances when the women themselves eat less food, at times even starved and gave more food to the men and the other members of the family. This could have serious implications on the health of women and girls.

The lockdown imposed as a preventive measure to contain the corona virus pandemic has magnified the plight of the single women including younger, older, middle aged, widows etc., as they are responsible for their own safety, mental health and financial stability. Without any lack of support for these women due to the social stigma attached to single women there is an increase in the level of anxiety and fear of being unsafe amongst them.

Another issue which is of concern in this pandemic is the escalation of violence against women in the country during the lockdown period. In the chaos resulting from the crisis and the disruption caused to social and family protection, vulnerability of all women increases in terms of personal security. And what is important to note is that the violence which a woman encounters at home, the perpetrator is none other than the husband or close relatives. The consequences of violence against women are seen to affect all aspects of the everyday life of the women, especially her health (Watts and Zimmerman, 2002; UNIFEM, 2003; WHO, 2001; WHO, 2005).

Another category of population who are more vulnerable in the pandemic is the elderly. The elderly populations above 60 years of age are at more risk of getting infected by the virus and even death. The impact of social distancing and lockdown has been particularly tougher for the older adults as it has led to isolation and loneliness which is having a negative impact on their mental health as they more confused and are losing orientation of their surroundings. This is having an impact on their immunity.

People's exposure to the virus also differed if they were disabled as they had certain special needs. The lockdown has increased the problems of the people with disabilities, for instance of the deaf and mute as they found it difficult to access the food and everyday requirements as neither the police nor the response teams from the government understand sign language. The people with disabilities also found it difficult to get caregivers and helpers 
during the pandemic as there was no one to attend to their special needs as a consequence of which neither they could get access to medicines nor could make medical visits.

There is another category of population who is worst affected in the pandemic is the transgenders. These people for their daily sustenance depend on begging, ritual functions and sex work, which can only be met through social contact. This puts them at a higher risk of contracting the virus than the general public.

In the corona virus outbreak migrants were most vulnerable as they not only lost their employment and wages; with it they also lost their access to housing. This prompted a painful and chaotic process of mass return of migrants from urban to rural areas of origin, which threaten to worsen the already precarious rural livelihoods; this made them more vulnerable to exploitation and abuse. For e.g. in a distressful incident in Uttar Pradesh the migrants who were returning home were sprayed with a chemical disinfectant by a team who were on sanitizing duty at Bareily bus stop.

This shows how even a pandemic situation vulnerability of people differed in varying ways and with differing magnitude on the basis of caste, class, age, gender, disability, migrant status. It showed how the social systems operate to engender by making the impact of a pandemic more severe on some vulnerable groups and individuals.

\section{CONCLUSION}

The study revealed how pandemics can be identified within the broader patterns of society. It explored the connections between the risks different categories of population face and the reasons for their vulnerability to crisis. This analysis from a sociological perspective may provide a more effective way of formulating policies that can help to reduce and mitigate the effects of pandemics, while at the same time bettering the living conditions and opportunities of people more inclusively.

In risk society the unknown and unintended consequences come to a dominant force in society as it is evident in the corona virus outbreak. For instance - when the government of India imposed the strictest lockdown in response to the pandemic, it was unknown and one of the unintended consequences of the lockdown was that the unemployment rate tripled in India. Since risks are an incidental problem of modernization in undesirable abundance, it can be eliminated by proper preparedness and response plan, which is also applicable in the present corona virus pandemic. In circumstances where human actions are causing harm to the people on a global scale "precautionary measures" are needed. Since the government of India spends just 1.28 percent of its GDP on public health expenditure as per 2017-18 data, we could hardly get around establishing a truly effective pandemic preparedness system. To prevent the pandemic from disrupting the daily life of the people and wiping out towns and killing people, it is crucial to invest in preparedness and not panic. There should be a separate provision for pandemic funding in the budget of the government of India.

Another approach to be prepared for unforeseen circumstances arising out of pandemics is to have a health disaster mitigation training centre which can prepare doctors, nurses and paramedical professionals with state-of-the-art training for immediate deployment during future health exigencies.
Since the enormity of the problem demands a decentralized approach, a new provision was introduced by the government of Odisha, i.e. a community based monitoring strategy to contain the spread of the novel corona virus by delegating the sarpanches the "collector's power" so that they can plan, coordinate and take steps within their jurisdiction. This can pave the way for other states to introduce new strategies for the involvement of panchayati raj institutions which are people's institutions at the grassroots level; this can go a long way for effective pandemic management.

\section{REFERENCES}

Books and Journals

[1] Alexander, D. (1983), Natural disasters, (New York: Chapman and Hall).

[2] Ariyabandu, M.M and Wickramasinghe, M (2003), Gender Dimension in Disaster Management: A Guide for South Asia, ITDG South Asia.

[3] Beck, Ulrich. (1992), Risk Society: Towards a New Modernity, Theory, Culture and Society, (London, Newbury Park, New Delhi: Sage Publications)

[4] Blaikie, P., P.T. Cannon, I. Davis, and B. Wisner (2nd ed.) (2003), At Risk: Natural Hazards, People's Vulnerability, and Disasters, (London: Routledge).

[5] Chang, K.S (ed.) (2017), Reflexive Modernization, John Wiley and Sons Publications.

[6] Eid, M. (2003), "Reflexive Modernity and Risk Society", International Journal of humanities, Vol. 1, pp.813-828.

[7] Leiss, W and B. Wynne (1995), "Risk Society, towards a new modernity", Canadian Journal of Sociology, Vol.19, No.4, pp. 544 - 547.

[8] Mileti, D.S., T.E. Drabek and J.E. Haas (1975), Human Systems in Extreme Environments, (Boulder CO: Institute of Behavioural Science, University of Colorado).

[9] Pandemics: A Brief History (2020), https://www.amazon.com/PandemicsBrief-History-University-Press-ebook/dp/B086XFM9XL, University Press.

[10] Sadati, A.K., M.H. Lankarani, and K.B. Lankarani (2020), "Risk Society, Global Vulnerability and Fragile Resilience: Sociological View on the CoronaVirus Outbreak", Shiraz E-Medical Journal, March.

[11] South Asian Disaster Report 2005: Tackling the Tides and Tremors, (2006), Pictoral Printer Pvt Ltd. Newspaper/Magazines

[12] “At 1.28\% of GDP, India's expenditure on health is still low although higher than before", The Print, 31st October, 2019.

[13] 'Centre invokes 'epidemic act' and disaster management act' to prevent spread of corona virus", The Times of India, 12th March, 2020.

[14] "Coronavirus and Caste: Is our response to the pandemic casteist", The Quint, 21st March, 2020.

[15] "Coronavirus and Covid-19: Caregiving for the elderly", Health, https://www.hopkinsmedicine.org/health/conditions-anddiseases/coronavirus/coronavirus-caregiving-for-the-elderly

[16] "Coronavirus: India's partial lockdown reeks of class, caste bias leaving socially, sexually disadvantaged groups vulnerable”, Outlook, 22nd March, 2020

[17] "Coronavirus: lockdown in India has affected 40 million migrants, says World Bank", Business Today, 23rd April, 2020.

[18] "Covid-19 is becoming the disease that divides us: by race, class, and age", Bloomberg, 21st March, 2020.

[19] “Covid-19: 'Dharma Sankat' for government over lockdown”, The Times of India, 9th April, 2020.

[20] "Covid-19: Social Distancing and Lockdown most Potent Vaccine", The Times of India, 9th April, 2020.

[21] Covid -19 and the anti-lessons of history, Lancet, 2nd march, 2020

[22] "Double Whammy: Corona Virus threat, fear of Job Loss", The Times of India, 10th April, 2020.

[23] "Four Water Bottles, Five Mobiles and A Migrant Family on the Move", The Times of India, 31st March, 2020. 
[24] "How Covid-19 Lockdown has hit disabled people hard", The Times of India, 6th April, 2020.

[25] "How literature has helped us make sense of Pandemics", The Times of India, 27th March, 2020.

[26] "How we made corona virus pandemic", The Times of India, 7th April, 2020.

[27] "Hungry, desperate: India virus controls trap its migrant workers", Aljrazeera, 2nd April, 2020.

[28] "ICMR: Isolation may cut peak coronavirus number by $89 \%$ ", The Times of India, 25th March, 2020.

[29] "India cannot fight coronavirus without taking into account its class and caste divisions", Scroll .in, 24th March, 2020.

[30] "India declares corona virus 'notified disaster', many public places shut", The Times of India, 15th March, 2020.

[31] "Lockdown Extension Likely as PM talks of National Emergency", The Times of India, 9th April, 2020.

[32] "Odisha minister suggests health disaster training centre for future disaster exigencies", The Times of India, 17th April, 2020.

[33] “Outbreak in slum forces Mumbai to confront its 'shame': Ratan Tata", The Times of India, 21st April, 2020.

[34] "Preparing for pandemics such as coronavirus - will we ever break the vicious cycle of panic and neglect?" Future Development, 11th February, 2020.

[35] "Preventing the next pandemic- we can make this a 'never again' moment", The Times of India, 7th April, 2020.

[36] "Sarpanches in Odisha to get collectors' power for effective covid-19 management", The Times of India, 20th April, 2020.

[37] "The Big Dilemma: Saving Lives vs Saving Livelihoods", The Times of India, 10th April, 2020.

[38] "The covid -19 lockdown will ravage prospects for India's female workforce", The Wire, 15th April, 2020.
[39] "The Covid-19 Riddle: Why does the virus wallop some places and spare others", The New York Times, 3rd May, 2020.

[40] "Times Evoke: Eating Animals is degrading and damaging - it yield better harvest", The Times of India, 7th April, 2020.

[41] "Under India's caste system, dalits are considered untouchables; the coronavirus is intensifying that slur", CNN, 16th April, 2020.

[42] "When a Pandemic Points to a Constitutional Crisis", The Times of India, 9th April, 2020.

[43] "Why Covid-19 is Nothing like the deadly Spanish Flu", The Times of India, 14th March, 2020.

[44] "Why the lockdown is harder on single women", The Times of India, 23rd April, 2020.

[45] "Why women are more stressed that men during lockdown", The Times of India, 17th April, 2020.

[46] "With migrant workers on a desperate march home, states must act", The Times of India, 27th March, 2020.

[47] "With Migrants Leaving Cities, Joblessness Spike", The Times of India, 8th April, 2020.

\section{AUTHORS}

First Author - Dr.Niharika Mohapatra, is a post-doctoral fellow, ICSSR, after completing her doctorate from Jawaharlal Nehru University, New Delhi, in the Centre for the Study of Social Systems, School of Social Sciences. Her research interest is disaster studies., Email-id: mohapatra.niharika@gmail.com 